\title{
New data and description of new species of bark beetles (Coleoptera: Curculionidae: Scolytinae) from east slope of Cordillera Vilcabamba of Peru
}

\author{
Новые данные и описание новых видов короедов \\ (Coleoptera: Curculionidae: Scolytinae) с восточных склонов \\ Кордильеры Вилькабамба республики Перу
}

\begin{abstract}
A.V.Petrov
A.B. Петров

Institute of Forest Science, RAS, Sovetskaya st., 21, Uspenskoe, Moscow Region, 143030, Russia. E-mail: hylesinus@list.ru Федеральное государственное бюджетное учреждение науки Институт лесоведения Российской академии наук, ИЛАН РАН, Российская Федерация,143030, Московская область, Одинцовский район, с. Успенское, ул. Советская, д.21
\end{abstract} Peru.

KEY WORDS: Coleoptera, Curculionidae, Scolytinae, bark beetles, taxonomy, Cusco, Cordillera Vilcabamba,

КЛЮЧЕВЫЕ СЛОВА: Coleoptera, Curculionidae, Scolytinae, короеды, систематика, Куско, Кордильера Вилькабамба, Перу.

ABSTRACT. Three new species of Scolytinae (Coleoptera: Curculionidae) are described from the Cusco region of Peru: Micracis wataensis, Pseudothysanoes tecomi and Xylechinus smithae spp.n.. New records of bark beetles in the forest communities of the Cordillera Vilcabamba are given.

РЕЗЮМЕ. Описаны три новых вида короедов (Coleoptera: Curculionidae) из региона Куско Республики Перу: Micracis wataensis, Pseudothysanoes tecomi, Xylechinus smithae spp.n. Приведён список видов короедов, найденных в лесных сообществах Кордильеры Вилькабамба.

The Neotropical Region can be still defined as "terra incognita" for Scolytinae researchers. S.L.Wood [2007] estimated that only a third of the fauna was described for Peru. The montane forests of Peru are of special interest for study. The climate and relief of the mountainous regions of Peru impact the diversity of species of trees and shrubs in the areas over 2500-3000 $\mathrm{m}$ above sea level (a.s.1.). The forests of the East Cordillera mountains (Cordillera Oriental) differ considerably from the forests along the Amazon River basin and from the Central piedmont selva growing at 120 to $1500 \mathrm{~m}$ a.s.1. Every $450 \mathrm{~m}$ the average temperatures drops around $1.7^{\circ} \mathrm{C}$ dramatically reducing the rainfall amounts. The change of vegetation affects the composition of the xylophage insects in the mountane ecosystems. The author studied the forests along the Eastern slopes of the Cordillera of Vilcabamba (Cusco region) near the ruins of the former Incan fortress Watá, 3000-3900 m a.s.l. The studies were performed in 1997, 2006 - 2014 years. For many centuries the area was heavily affected by farming and grazing dating back to Incan times. The height of $3900 \mathrm{~m}$ is the upper boundary for the tree vegetation. The slopes are sparsely covered by introduced Eucalyptus (Myrtaceae) and Juniperus (Cupressaceae) and some species of Tecoma (Bignoniaceae) and, Senna (Fabaceae), and Flourensia (Asteraceae) shrubs covered by vines. At $2900-3100 \mathrm{~m}$ a.s.1. the Tecoma trees form closed forests.

From this area Chramesus peruanus Schedl, 1961 (one male from Urubamba) has been described earlier [Schedl, 1961]. A big series of bugs of this species has allowed to redescribe Ch. peruanus [Petrov, Mandelshtam, 2011]. The author earlier described Pseudothysanoes (Bostrichips) vorontsovi Petrov, 2009, Pityophthorus maslovi Petrov, 2015 and P. vilcabambensis Petrov, 2015 from the Watá region [Petrov, 2009, 2015].

ABBREVIATIONS: APP - Alexander Petrov private collection, Moscow, Russia; MSUC - Albert J. Cook Arthropod Research Collection, Michigan State University, East Lansing, USA; NHW — Naturhistorisches Museum Wien, Vienna, Austria; ZMM Zoological Museum of Moscow State University, Moscow, Russia.

Tribe Hylurgini Gistel, 1848

Genus Xylechinus Chapuis, 1869

Xylechinus smithae Petrov, sp.n.

Figs 1-8.

MATERIAL. Holotype, $0^{7}$ : PERU: Cusco region, Eastern slopes of the Cordillera Vilcabamba, $34 \mathrm{~km} \mathrm{NW}$ from Cusco, left river bank of Huarocondo, Watá, h $3150 \mathrm{~m}, \mathrm{~S} 13^{\circ} 21.347^{\prime} \mathrm{W} 72^{\circ} 14.470^{\prime}$, ex. Passiflora sp., 26.01.1997, A.Petrov. Paratypes: $1 O^{7}$ and 2 O +9 in same site and date (Petrov collection and $1 O^{7}$ MSUC). 
TYPE LOCALITY: Peru, Cordillera Vilcabamba.

DESCRIPTION. Male (Figs 1, 3, 5, 7): total length 1.7 $\mathrm{mm}, 2.0$ times as long as wide; body dark-brown, covered with variegated scales ( 60 percent pale brown and 40 percent light grey); antennae and legs reddish-brown.

Head dark-brown; frons flat, its surface faintly shining, covered in light scale-like hairs, hairs at lateral frontal margins dense, closely spaced and are raised, and thickened, in comparison with the center of frons, these hairs in a horseshoe-shaped form around the center of the frons, hairs in central part of frons are thinner and are only slightly raised over surface; thin brushes of long thin hairs hang over the top of the mandibles; vertex with adjacent short scale-like hairs; eye large, entire, 4 times as long as wide. Antenna red-brown, length of scapus almost equal to the length of club, scape with a long pale hairs, forming a dense long brush, the length of the brush equal to the length of the scape and club, antennal funicle 5-segmented, club conical to elliptic (2.5 times as long as wide), weakly flattened, 3segmented, covered by very short pale hairs, with two transverse sutures, the third segment of the club slightly pointed.

Pronotum wide ( 0.75 times as long as wide); lateral sides evenly rounded to apical part; pronotum without elevated crenulations; central part of elytral bases bent toward scutellum, surface covered with variegated scales, 75 percent pale brown scales on the disc and 25 percent light grey on the base and apical part of pronotum.

Scutellum is depressed below the level of the elytral base, small.

Elytra brown, shining, 1.28 as long as wide; 2 times longer then pronotum, basal margin of elytra procurved and armed by a series of marginal crenulations, lateral sides are parallel on anterior two-thirds, rounded on the posterior third of its length, declivity rather convex. Elytral surface punctured by small points often hidden under scales; the wide longitudinal area along the first striae is impressed, shining, without vestiture from the elytral base to posterior part of elytra, this dark line not reaching elytral apex; sutural interstriae weakly elevated with erect scales; other surfaces covered by variegated rounded scales ( 60 percent pale brown and 40 percent light grey), bicolor scales forming the indistinct marbled pattern on elytral surface, elytral interstriae with rows of elongate erect pale scales.

Abdomen dark-brown, plumose scales forming horizontal rows in apical sides of each segment.

Legs reddish-brown with erect pale hairs.

Female (Figs 2, 4, 6, 8): larger than males, length of 2.2$2.3 \mathrm{~mm}$, scales on body mostly brown (90 percent brown and 10 percent light grey); frons weakly convex, vestiture of head dark; scape of antenna with short pale hairs without brushes; structure and vestiture of elytra same as male, elytral interstriae with row of light scales.

DIAGNOSIS. Species differs from other Xylechinus by expanded and impressed first striae and second interstriae area on the elytra, without vestiture and with a long brush of very long, pale hairs on scape of male's antenna.

DISTRIBUTION. Known only from type locality.

HOST. Liana Passiflora sp. (Passifloraceae)

BIOLOGY. Monogamous species. Adult attacked dying lianas. The galleries are entirely in the phloem and wood near the surface of reinforced knot of a branching liana. Beetles were collected in transversal cave-shaped tunnels

ETYMOLOGY. The new species is named in honor of the fearless researcher of Scolytinae Sarah M. Smith (Michigan State University, USA).
Tribe Phloeosinini Nuesslin, 1912

Genus Chramesus LeConte, 1868

Chramesus peruanus Schedl, 1961

MATERIAL. PERU: Urubamba, Olontaitambo, Dep. Cruzea, Peru, 31.I.1949, G. Kuschel (Holotype, NHW); PERU: Cusco region, Eastern slopes of the Cordillera Vilcabamba, $34 \mathrm{~km} \mathrm{NW}$ from Cusco, left river bank of Huarocondo, Watá, h $3100-3640 \mathrm{~m}$, $72^{\circ} 14^{\prime} \mathrm{W} 13^{\circ} 21^{\prime} \mathrm{S}\left(560^{7} 0^{7}\right.$ and 36 우).

REMARCS. This species may be distinguished from Chramesus phloeotriboides Schedl, 1958 by the scale-like setae on the interstriae and by the abruptly projecting upper margin of the lateral crest of the frons in males.

DISTRIBUTION. Peru: Urubamba and Apurimac River valleys. The species meets in xylium with host tree on slopes from 3200 to $3800 \mathrm{~m}$ a.s.1.

HOST. Senna birostris (Dombey ex Vogel) H.S.Irwin et Barneby (Fabaceae).

BIOLOGY. Monogamous species. Adults of Ch. peruanus attack the main trunk and limbs of host trees. The entrance tunnel is started at the base of a twig. Longitudinal egg galleries (7-35 $\mathrm{mm}$ long) deeply engrave the wood of forks of branches of a tree, up to 3-25 eggs per gallery are placed singly in niches along the gallery walls. The larval mines engrave the wood. Pupal cells are constructed entirely in the wood. The life cycle required $32-40$ days.

Genus Phloeosinus Chapuis, 1869

\section{Phloeosinus sp.}

MATERIAL: PERU: Cusco region, Cordillera Vilkabamba, 34 km NW from Cusco, left river bank of Huarocondo, Watá, h 3100 m, ex Juniperus sp., 26.01.1997, A. Petrov. Two dead females were collected in egg galleries on main trunk of Juniperus sp.

BIOLOGY. Not investigated in Peru. The host trees are not native to Peru. Likewise there are no native species of Phloeosinus known from South America so it is very likely that this species has been introduced from North America or Eurasia. Males are normally required for identification.

Tribe Micracidini LeConte, 1876

Genus Micracis LeConte, 1868

Micracis wataensis Petrov, sp.n.

Figs 9-16.

MATERIAL. Holotype, ơ (ZMM): PERU: Cusco region, Eastern slopes of the Cordillera Vilcabamba, $34 \mathrm{~km} \mathrm{NW}$ from Cusco, left river bank of Huarocondo, Watá, $13^{\circ} 22.151^{\prime} \mathrm{S} 72^{\circ} 14.409^{\prime} \mathrm{W}$, h 3100 m, 26.01.2006, A. Petrov; Paratypes: same place and date $3 O^{7} O^{7}$ and $3 O^{7} O^{\top}$ (in APP).

TYPE LOCALITY: Peru, Cordillera Vilcabamba.

DESCRIPTION: Male: total body length $3.20 \mathrm{~mm}, 3.2$ times as long as wide, body reddish-brown, covered with pale scales.

Head black, dull; frons broadly convex from epistoma to vertex, without impressed areas; surface subreticulate with numerous fine granules, with sparse short dark hairs uniformly distributed; frons punctured by sparse microscopic small points; surface of vertex similar to frons; eyes elongate-oval, 2.3 times as long as wide; antenna with a weak flattened scape (2.3 times as long as wide) with erect long pale hairs, funicle 6-segmented, antennal club elongate-oval, 1.8 times as long as wide, length of the club equal to that of the funicle, sutures 1 and 2 of the club strongly procurved, marked by setae; mandibles small, triangular with a small subapical tooth, mola convex; labium elongate with raised crest of the elongate ligula; maxilla with long cardo, five lateral teeth (close to cardo) have the bristleless form. 
Pronotum reddish-brown, surface weakly shining, 1.25 times as long as wide, lateral margins parallel in the center half and broadly rounded in basal corners and apex; summit slightly anterior to middle, anterior slope coarsely asperate, anterior margin armed by six rather coarse serrations, posterior part with coarsely shagreened, finely and sparsely punctured by very small points; surface in anterior half covered by long erect hairs and in posterior half by very short light scales and

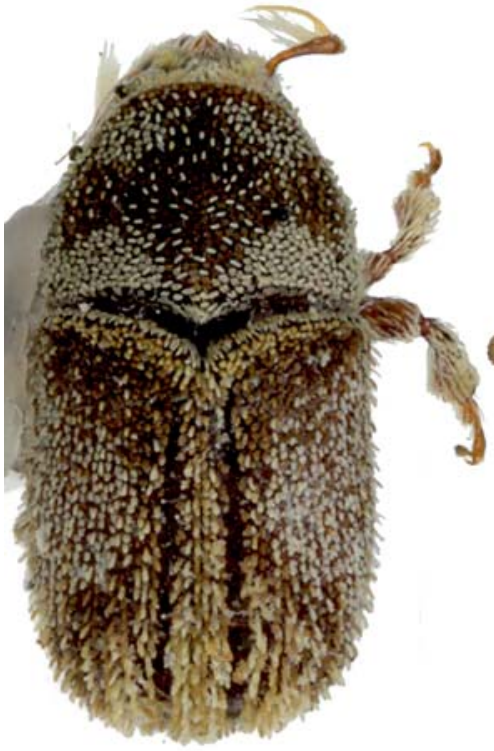

1
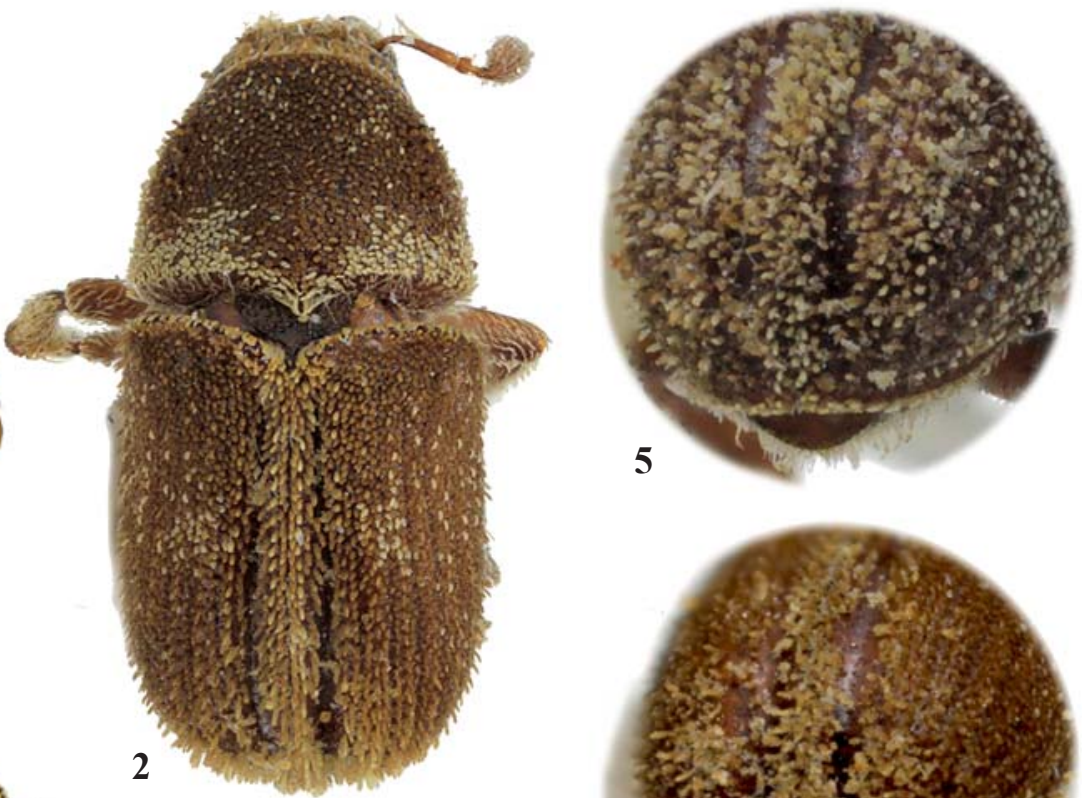

6

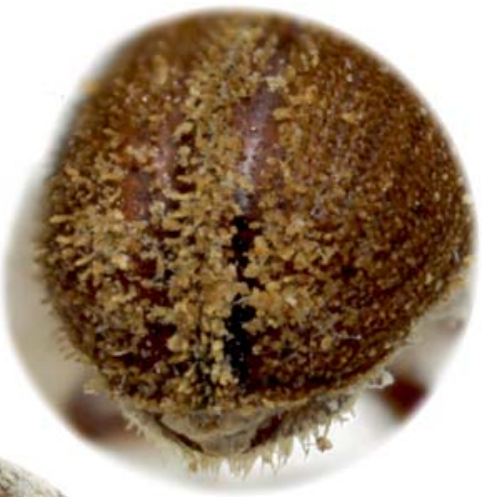

3
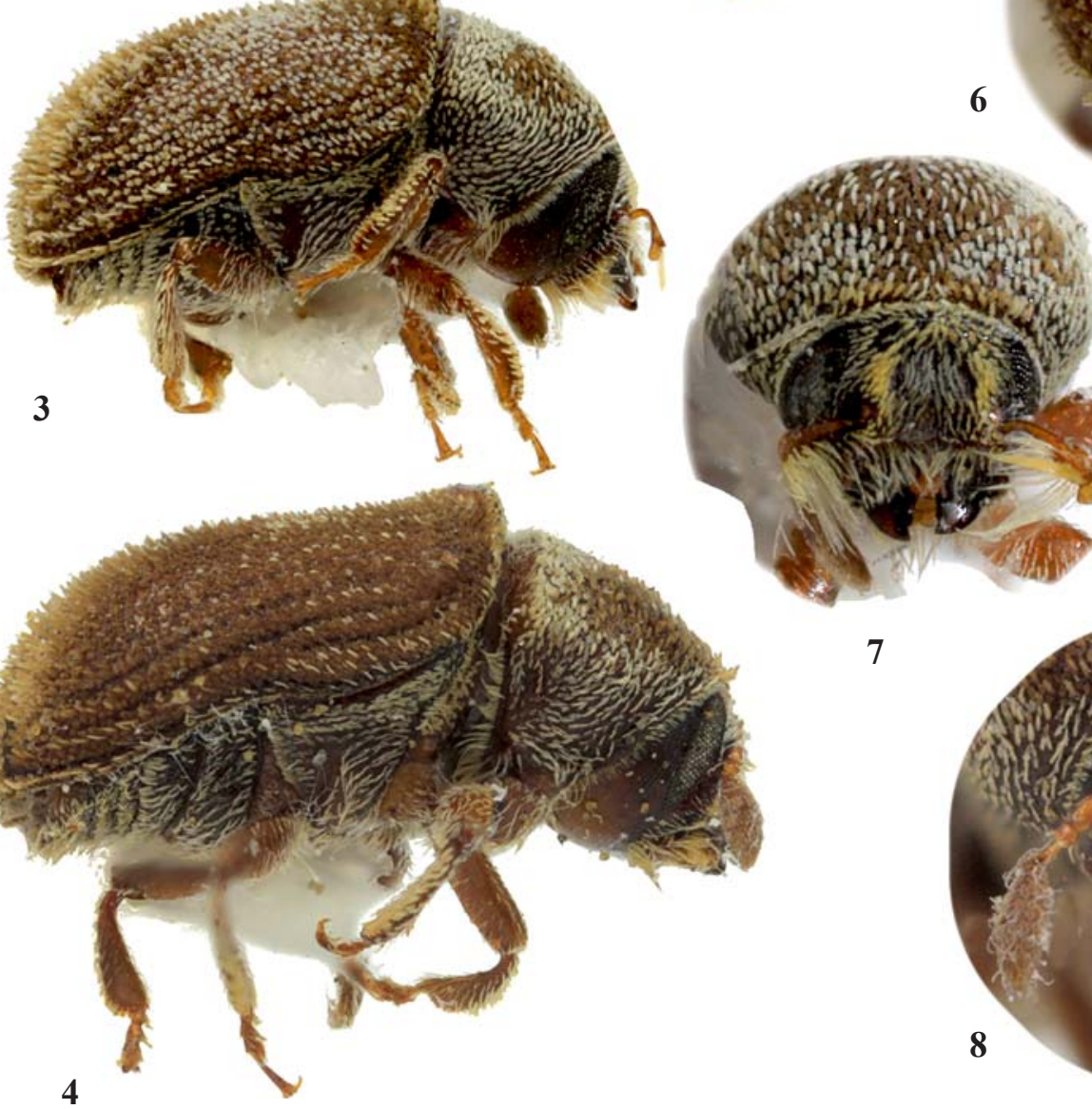

(2)

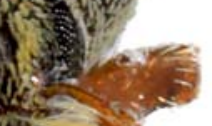

IN
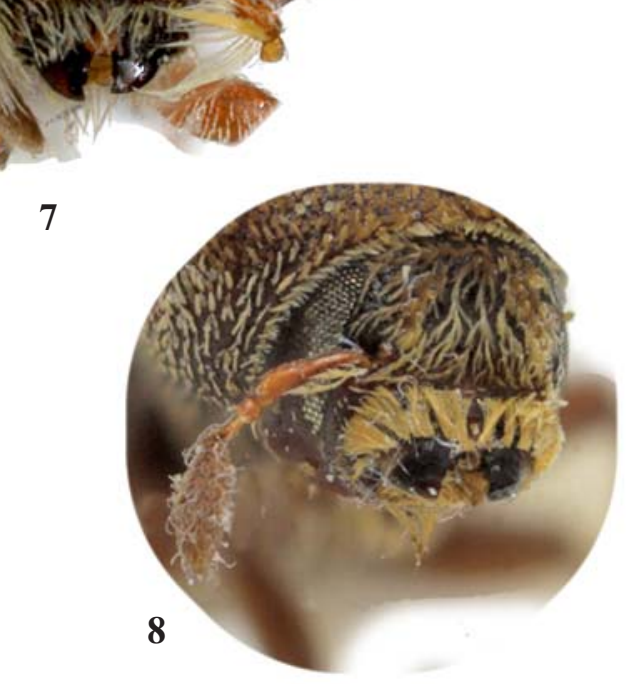

Figs 1-8. Xylechinus smithae sp.n: 1-2 - habitus, dorsal view; $3-4$ - habitus, lateral view; 5-6 - declivity; $7-8$ - frons; $1,3,5,7-$ holotype, $0^{7} ; 2,4,6,8$ - paratype,, .

Рис. 1-8. Xylechinus smithae sp.n: 1-2 - внешний вид, сверху; 3-4 - внешний вид, сбоку; 5-6 - скат надкрылий; 7-8 - лоб; $1,3,5,7$ - паратип, $0^{7} ; 2,4,6,8$ - паратип, + . 
adjacent short hairs. Scutellum small, dark-brown, rounded. Elytra reddish-brown, weakly shining, 2.0 times as long as wide, 1.8 times as long as pronotum, disc occupying about 75 percent of elytra length, posterior quarter broadly round- ed, declivity broadly convex, apices weakly acuminate; striae not impressed, wide, twice as wide as interstriae, punctures deep and large, are closely spaced in rows, but not confluent, interstriae narrow, with row of small points; surface covered
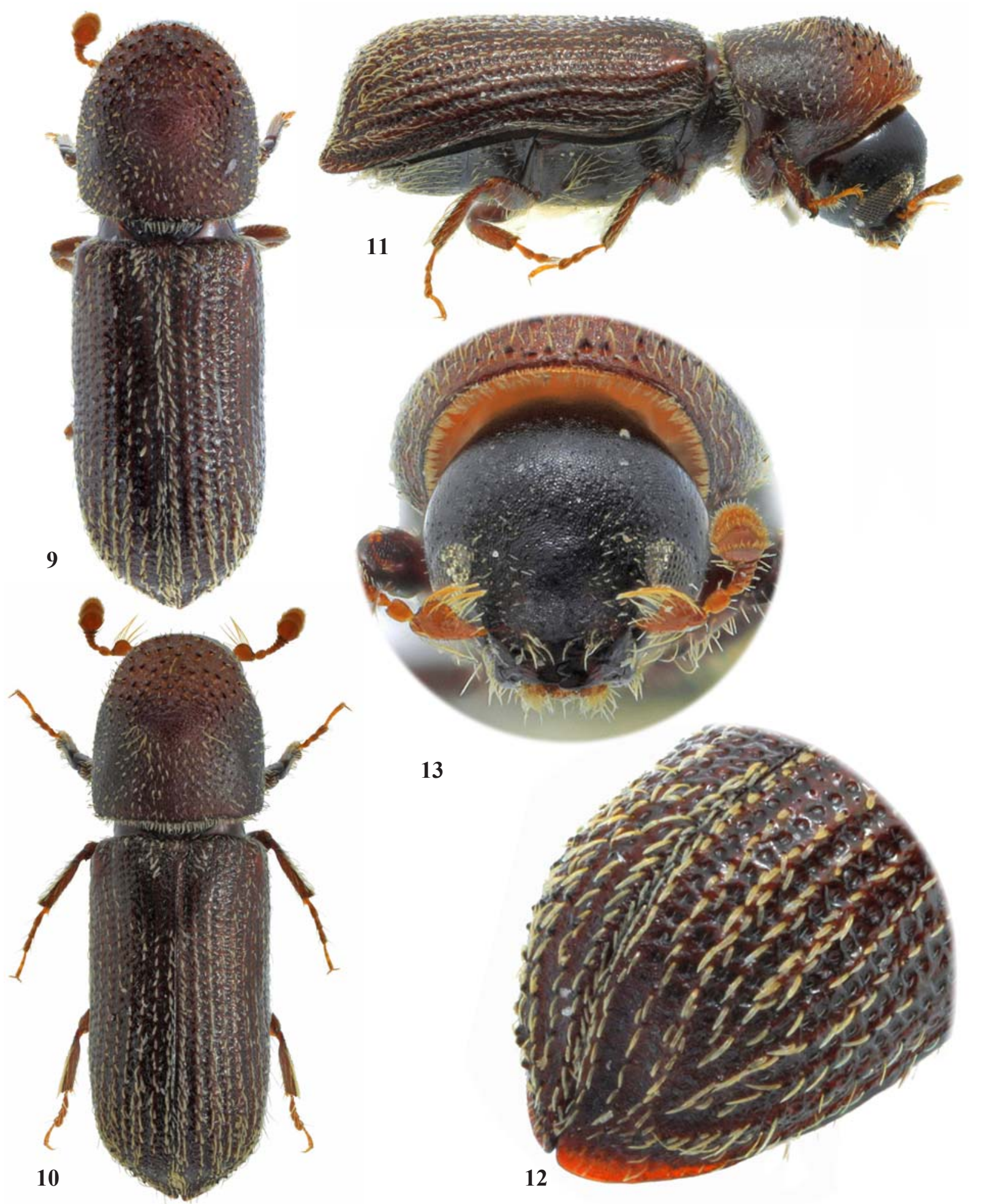

13

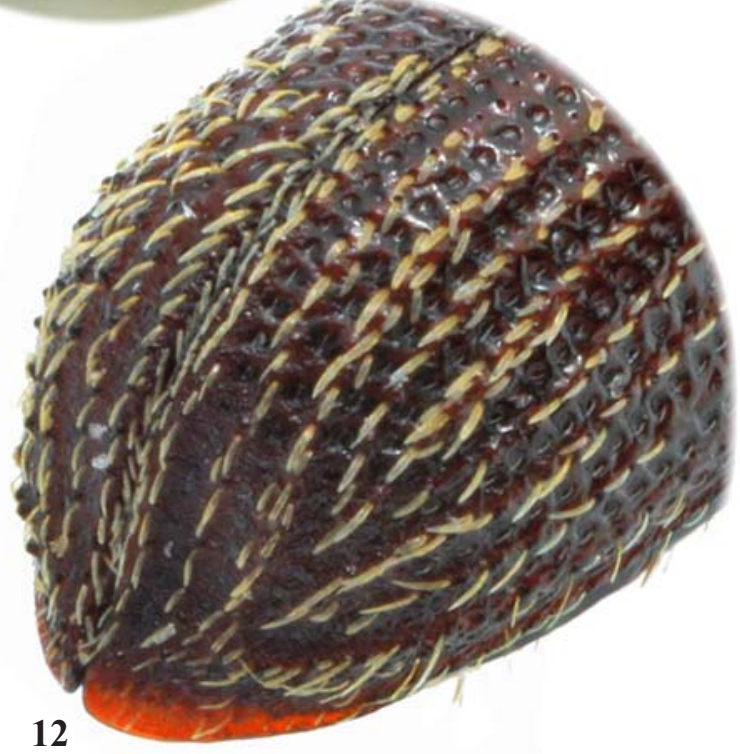

Figs 9-13. Micracis wataensis sp.n: 9-10 — habitus, dorsal view; 11 — habitus, lateral view; 12 - declivity; 13 — frons; 9 - holotype, $\mathrm{O}^{7} ; 10-13$ - paratype, ㅇ.

Рис.9-13. Micracis wataensis sp.n: 9-10 - внешний вид, сверху; 11 - внешний вид, сбоку; 12 - скат надкрылий; 13 - лоб; 9 - голотип, O; $10-13$ - паратип, + . 
by scales and scale-like setae, interstriae on disc with short pale scales, in posterior quarter of the elytral length scale-like setae are longer and more abundant.

Sternum black, shining, finely shagreened, weakly punctured by points with long pale setae. First and second sternites black, elongate, deeply punctured by rounded points, covered by long pale setae; third, fourth and fifth sternits reddish-brown, short (3.0 times as short as second sternite), with short setae.

Legs covered by light hairs, femur and tibia are dark reddish-brown, tarsus is brown. Protibia broadly flattened, with one doubled tubercle on apical margin.

Proventriculus (Fig. 14): the morphology of proventriculus is typical for Micracis [Lopez-Buenfil et al., 2001]. Anterior plate with six crossed lines of teeth (brushes). Proventriculus in transitional area between anterior and posterior plates with three lines of brushes. The lines of brushes of this area continuous with lines of teeth of anterior plate.

Genital morphology (Figs 15-16): aedeagus elongate, 3.1 times as long as wide; form of median lobe is boatshaped, subconical, lateral margins sclerotized, proximal third parallel sided, apex narrowly acute; apophyses very long, length of apophyses 2.4 times as long as aedeagus; tegmen circular with the long shoot, extended along apophyses; spicula almost straight from top to the lower part, it's doubled in the lower part on two pointed short outgrowths. Aedeagus with two long thin basic supporting structures, apex of aedeagus with two very small transparent plates.

Female (Figs 10-13): similar to male except more slender, total body length $3.30 \mathrm{~mm}, 3.3$ times as long as wide, frons flattened in lower part from epistoma to lower part of

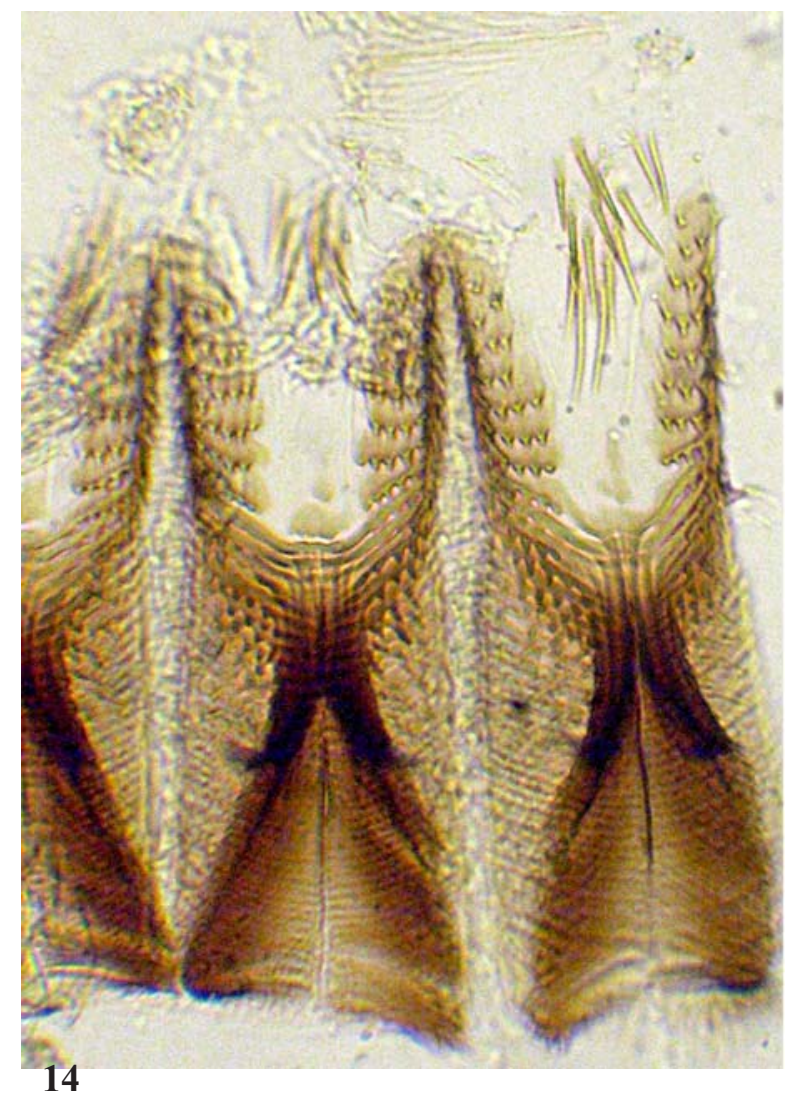

eyes, scape triangularly expanded, wider than long, ornamented by tuft of long setae; anterior margin of pronotum unarmed; elytral vestiture more abounded.

Note: total body length of paratypes: males $2.5-3.2 \mathrm{~mm}$, $3.0-3.2$ times as long as wide, females $3.35 \mathrm{~mm}, 3.2-3.3$ times as long as wide.

DISTRIBUTION. Known only from type locality.

HOST. Herbaceous plant in the Asteraceae.

BIOLOGY. Long egg gallery in the core of herbal stalk.

ETYMOLOGY. The name of the new species is derived from the Watá, where the types was collected.

Genus Pseudothysanoes Blackman, 1920

\section{Pseudothysanoes (Bostrichips) tecomi Petrov, sp.n.} Figs 17-22.

MATERIAL. Holotype, O' (ZMM): PERU, Cusco region, Eastern slopes of the Cordillera Vilcabamba, $34 \mathrm{~km} \mathrm{NW}$ from Cusco, left river bank of Huarocondo, Watá, h 3300 m, S 13 ${ }^{\circ} 22.151^{\prime} \mathrm{W}$ $72^{\circ} 14.409^{\prime}$, ex. Tecoma sp., 26.01.1997, A. Petrov; Paratypes: 25 $\sigma^{7} \sigma^{7}$ and 37 of in same locality on a slope from $3100 \mathrm{~m}$ to $3500 \mathrm{~m}$ a.s.1., 26.01.1997, 26-28.01.2006, 13.02.2006, 8-9.04.2009, 35.03.2010, 27.03.2012, 6.05.2014, A.V. Pertrov (60 paratypes in APP and $1 O^{7}$ and 19 in MSUC).

TYPE LOCALITY: Peru, Cordillera Vilcabamba.

DESCRIPTION: Male: total body length $2.2 \mathrm{~mm}, 2.93$ times as long as wide, body cylindrical, dark-brown, covered with light hairs and scales, head is black, antennae and legs reddish-brown.

Head black, shining in epistomal area, other surfaces of head weakly shining to dull; frons convex, surface from epistoma to vertex finely granulate; vestiture of sparse, very

Figs 14-16. Micracis wataensis sp.n., paratype, $\sigma^{7}: 14$ - proventriculus; $15-16$ - aedeagus; 15 - dorsal view; 16 - lateral view. Рис.14-16. Micracis wataensis sp.n, паратип, О: 14 - провентрикулюс; 15-16 - эдеагус; 15 - сверху; 16 - сбоку. 
fine, short setae; eyes short, 2.0 times as long as wide. Antenna reddish brown with dark-brown club, scape elongate (3.0 times as long as wide) with a small tuft of light hairs, antennal funicle 6-segmented, funicle and club with pale hairs of average length; club elongate-oval, 1.6 times as long as wide club, sutures 1 and 2 of procurved, marked by yellow setae. Mandibles triangular with small subapical tooth, molar part is convex; labium elongate with raised crest of the elongate ligula; maxilla with long cardo, five lateral teeth (close to cardo) have the a bristle-like form.

Pronotum dark reddish-brown, weakly shining, 1.03 times as long as wide, lateral sides subparallel from base to the center of pronotum, distinctly constricted on anterior half and broadly rounded on anterior margin; anterior with 6 small serrations; summit slightly anterior to middle, anterior slope coarsely asperate, posterior part weakly shining, reticulate, punctured by rounded points; surface of anterior half covered by erect hairs and in posterior half by short light scales and adjacent short hairs. Scutellum large, rounded.

Elytra dark reddish-brown, weakly shining, 1.96 times as long as wide, 2.16 times as long as pronotum; lateral sides subparallel from base to posterior part of the elytral length, posterior fifth part of elytral length broadly rounded, apical margin rounded. Surface of the disk finely punctured, with rows of deep round points, interstriae 1.3 times as wide as striae, interstriae 3 and 9 elevated and merge together on apical part of declivity (Fig. 19); striae of disc and declivity with very microscopic hairs, interstriae with erect short scalelike setae. Elytral declivity impressed, occuping less than $1 / 5$ of elytral length, surface flat, shining, rugose punctured by clear rows of deep points, striae about as on disc, lateral margins weakly raised. Base declivity of each elytra with two triangular, pointed spines on first and second interstriae, spines -1 and 2 equal in size (Fig. 20), posterior lateral margin with any microscopic small tubercles.

Sternum black, dull, finely shagreened, punctured by points with long light setae.

Abdomen dark brown to black. First and second sternites elongate, punctured by rounded points, covered by long light setae; third, fourth and fifth sternites very short (1/3 length of second sternite).

Legs reddish-brown covered by pale hairs. Protibia broadly flattened, without tubercle on apical margin. Meta- and mesotibias with long setae.

Proventriculus (Fig. 21): the morphology of proventriculus is typical for Micracidini [Lopez-Buenfil et al., 2001] Anterior plate with six crossed lines of teeth (brushes). Proventriculus in transitional area between anterior and posterior plates without lines of brushes.

Genital morphology (Fig. 22): aedeagus elongate, 2.3 times as long as wide; form of median lobe is boatshaped, proximal third with parallel marginns, apex broadly acute; apophyses very long, 5.0 times as long as aedeagus; tegmen circular with the long shoot; spicula is strongly procurved from top to the lower part, it's doubled in the lower part on two long pointed outgrowths.

Female (Fig.18): similar to male except with long tuft of setae on antennal scape; unarmed elytral declivity (or with very small tubercles).

DIAGNOSIS. The new species is closely related to Pseudothysanoes (Bostrichips) argentiniae (Schedl, 1958), but can be distinguished by impressed declivity with the pointed tubercles on the base of declivity and not elevated declivital interstriae 1.

DISTRIBUTION. Known only from type locality.

HOST. Tecoma sp. (Bignoniaceae).
BIOLOGY. Polygamous species, usually 2-3 females associated with one male. The galleries are entirely in the phloem and cambium near the surface of the wood. The male excavates the entrance hole and the nuptial chamber. Females construct an egg gallery radiating from the nuptial chamber. Length of egg gallery is 9-33 mm. Eggs are laid in niches cut into gallery wall, up to 2-12 eggs per gallery have been recorded. The larval mines engrave the phloem and pupation occurs in the phloem too. The life cycle required 50-65 days.

ETYMOLOGY. The new species is named according to host plant name Tecoma.

\section{Pseudothysanoes (Bostrichips) vorontsovi Petrov, 2009}

MATERIAL: PERU: Cusco region, Eastern slopes of the Cordillera Vilcabamba, $34 \mathrm{~km} \mathrm{NW}$ from Cusco, left river bank of

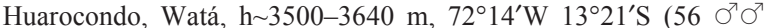
and 36 क + ).

DISTRIBUTION. Peru: Urubamba and Apurimac River valleys.

HOST. Flourensia angustifolia (DC.) S.F. BLAKE, 1836 (Asteraceae, Heliantheae)

BIOLOGY. Polygamous species, usually 3-5 females associated with one male. Adults of $P$. vorontsovi attack the dead or dying very thin and small limbs and tops of branches of the host shrubs or thick branches with mechanical damages. P.vorontsovi usually attacks at the same time as Pityophthorus maslovi attacks the thicker branches of the same host. The galleries are star-shaped with three to five egg galleries radiating from a central nuptial chamber. The length of egg gallery is 3-21 mm. Eggs are laid in niches cut into the gallery wall, up to $2-16$ eggs per gallery have been recorded. The larval mines engrave the phloem and pupation occurs in the phloem. The life cycle required 50-75 days.

Tribe Corthylini LeConte, 1876

Subtribe Pityophthorina Eichhoff, 1878

Genus Pityophthorus Eichhoff, 1864

Pityophthorus maslovi Petrov, 2015

MATERIAL: PERU: Cusco region, Eastern slopes of the Cordillera Vilcabamba, $34 \mathrm{~km} \mathrm{NW}$ from Cusco, left river bank of

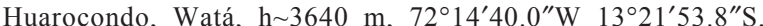
19.04.2009, ex. Flourensia angustifolia, leg. A.V. Petrov (Holotype, ZMM); same place, but 20.01.1997, 19.04.2010, 1.05.2012, 20.05.2014, ex. Flourensia angustifolia, leg. A.V. Petrov (58 $\sigma^{7} \sigma^{\top}$ and 87 + $)$.

REMARCS. This previously described species is distinguished from other Pityophthorus by transverse wrinkles on the elytral interstriae and coarse frontal reticulation with a well-marked longitudinal raised median carina from epistoma to upper part of the frons of male [Petrov, 2015].

DISTRIBUTION. Peru: Cusco, Cordillera Vilcabamba.

HOST. Flourensia angustifolia (DC.) S.F. BLAKE, 1836 (Asteraceae)

BIOLOGY. Polygamous species, usually 3-5 females associated with one male. Adults of $P$. maslovi attack the dying limbs or thick branches with mechanical damages. $P$. maslovi usually attacks at the same time as Pseudothysanoes vorontsovi attacks the thin branches of the host. The galleries are constructed under the bark, egg galleries scarcely touching the sapwood. The galleries are star-shaped with two to five egg galleries radiating from a central nuptial chamber. Length of egg galleries is $9-35 \mathrm{~mm}$. Eggs are laid in niches cut into gallery wall, up to 2-22 eggs per gallery have been recorded. The larvae feed in the phloem and pupation occurs in the phloem too. The life cycle required 50-65 days. 

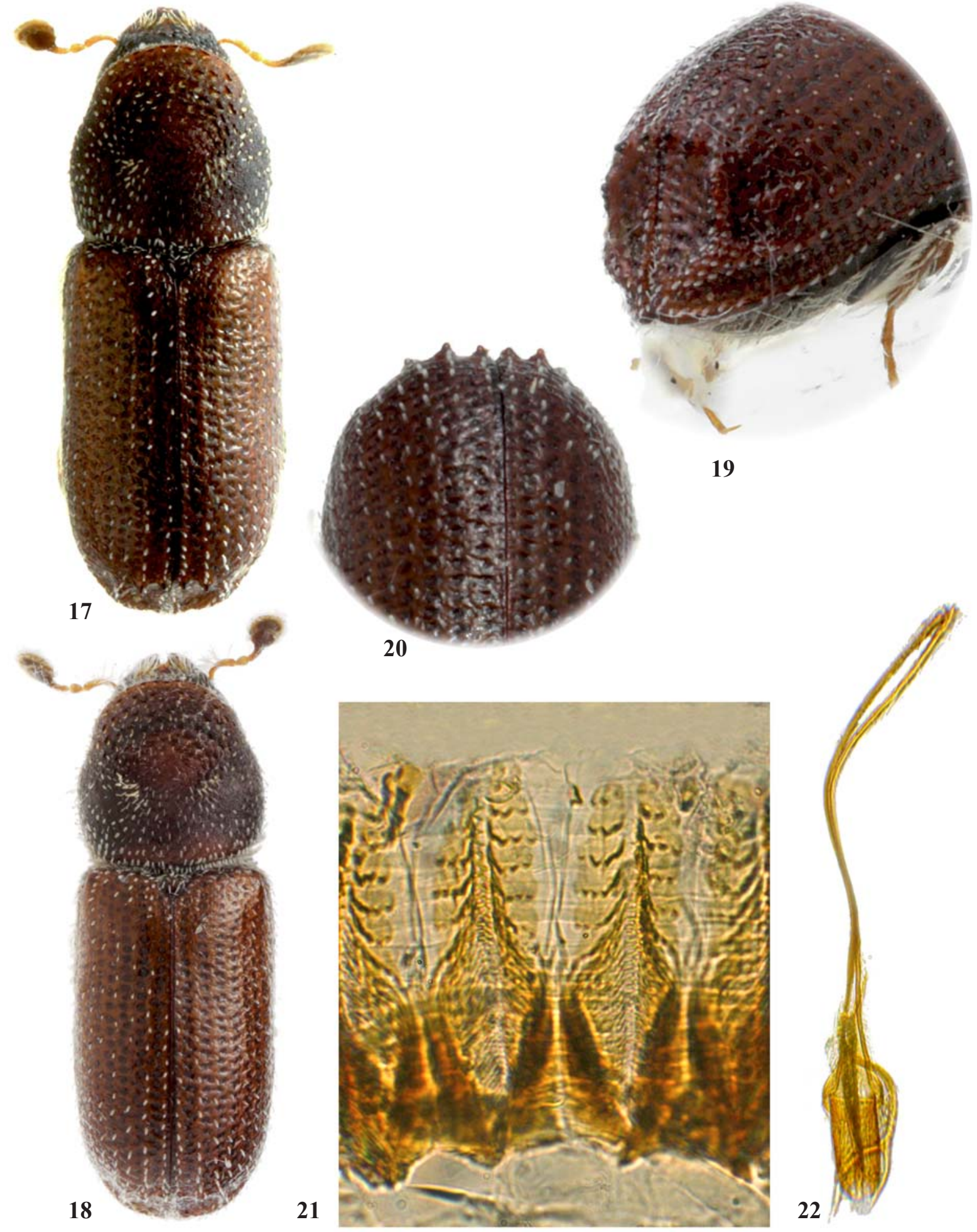

Figs 17-22. Pseudothysanoes tecomi sp.n: 17-18 - habitus, dorsal view; 19 - declivity; 20 - tubercles on the base of declivity; 21 proventriculus; 22 - aedeagus; 17 - holotype male; 18 - paratype,,$+19-22$ - paratype, $O^{7}$.

Рис.17-22. Pseudothysanoes tecomi sp.n: 17-18 - внешний вид, сверху; 19 - скат надкрылий; 20 - бугорки на основании ската надкрылий; 21 - провентрикулюс; 22 - эдеагус; 16- голотип, О7; 18 - паратип, ㅇ; 19-22- паратип, О?. 
Pityophthorus vilcabambensis Petrov, 2015

MATERIAL: PERU: Cusco region, Eastern slopes of the Cordillera Vilcabamba, $34.5 \mathrm{~km} \mathrm{NW}$ from Cusco, left river bank of Huarocondo, Watá, $3840 \mathrm{~m}$ a.s.1., $72^{\circ} 15^{\prime} 07.1^{\prime \prime} \mathrm{W} 13^{\circ} 20^{\prime} 59.6^{\prime \prime} \mathrm{S}$, 3.03.2010, ex. Gynoxys sp., leg. A.V. Petrov (Holotype. ZMM); same place but 9.04.2009, 25.12.2010, 27.03.2012, 4-6.05.2014 (88 Paratypes)

DIAGNOSIS: This previously described species in color is related to Pityophthorus minimus Wood, 2007 but distinguished by the structure of the frons, vestiture of elytral declivity; and from all species of Pityophthorus by combination of signs of coloring, structure of frons, and the character of declivity [Petrov, 2015].

DISTRIBUTION. Peru: Cusco, Cordillera Vilcabamba.

HOST. Bush Gynoxys sp. (Asteraceae). The species found in forests with its host on slopes from 3600 to $3850 \mathrm{~m}$ a.s.1.

BIOLOGY. Polygamous species, usually 2-4 females associated with one male. Adult of P.vilcabambensis attack the dying limbs of the bush after fires. The galleries are starshaped with two to four egg galleries radiating from a central nuptial chamber. Length of egg galleries is 4-28 mm. Eggs are laid in niches cut into gallery wall, up to $2-18$ eggs per gallery have been recorded. The larval mines engrave the phloem and pupation occurs in the phloem as well. The life cycle required 50-65 days.

ACKNOWLEDGEMENTS. The author expresses his most sincere gratitude to Dr. M. Jäch, Dr. H. Schilhammer,
Dr. H. Schönmann, (NHW, Wien) for the possibility to use the museum funds. The author would also like to acknowledge Dr. T.H. Atkinson (University of Texas, USA) and Dr. S.M. Smith (Michigan State University, USA) for critical reading of the text and improvement of the language.

\section{References}

Lopez-Buenfil J.A., Valdes-Carrasco J., Equihua-Martinez A., Burgos-Solorio A. 2001. El proventriculo como estructura para identificar generos mexicanos de Scolytidae (Coleoptera) // Folia Entomol. Mex. Vol.40. No.3. P.325-372.

Petrov A.V. 2009. The new data of Pseudothysanoes Blackman 1920 (Coleoptera: Curculionidae: Scolytinae) with described new species from Peru // Lesnoy Vestnik. No.5(68). P.128-130 [in Russian, with English summary].

Petrov A.V. 2015. Five new species of the genus Pityophthorus Eichhoff, 1864 from Peru (Coleoptera: Curculionidae: Scolytinae) // Koleopterologische Rundschau. Vol.85. P.319-32.

Petrov A.V., Mandelshtam M.Y. 2011. New data on bark beetles of the genus Chramesus LeConte, 1869 with descriptions of two new species from Peru (Coleoptera: Curculionidae: Scolytinae) // Koleopterologische Rundschau. Vol.81. P.269-275.

Schedl K.E. 1961. New species of bark- and timber beetles from the neotropical region. 186 Contribution // Pan-Pacific Entomologist. Vol.37. No.4. P.223-233.

Wood S.L. 2007. Bark and ambrosia beetles of South America (Coleoptera: Scolytidae). Provo: Monte L. Bean Life Science Museum, Brigham Young University, Utah. 900 p. 